\title{
A DILAÇÃO DE PRAZO PARA A INTERPOSIÇÃO DE RECURSOS ESPECIAL E EXTRAORDINÁRIO NOS TRIBUNAIS INFERIORES E A NOVA AFERIÇÃO DA TEMPESTIVIDADE PELOS TRIBUNAIS SUPERIORES
}

\author{
Vinícius Mendes e Silva ${ }^{1}$ \\ Rogerio Mollica ${ }^{2}$
}

\begin{abstract}
Resumo
O Novo Código de Processo Civil prevê normas fundamentais do processo, dentre elas o dever do juiz de zelar pelo efetivo contraditório, garantindo-se igualdade de tratamento entre as partes. Com isso, incumbe ao juiz dilatar prazos processuais. Todavia, em casos, como o dos recursos especial e extraordinário, que têm duplo de juízo de admissibilidade, esta dilação pode gerar problemas, quanto à admissão do recurso, em razão da competência para julgamento ser do tribunal Superior e a dilação de prazo ser concedida pelo tribunal de origem. Neste contexto, faz-se necessário conhecer não só os pressupostos recursais e regras de admissibilidade, como também os princípios envolvidos, para que se tenha, ao final, uma decisão justa.
\end{abstract}

Palavras-chave: contraditório efetivo. juízo de admissibilidade. prazo. recurso. segurança jurídica.

\section{THE EXTENSION OF TERM FOR THE SUBMISSION OF SPECIAL AND EXTRAORDINARY RESOURCES IN THE LOWER COURTS AND THE NEW STATEMENT OF TEMPESTIVITY BY THE HIGHER COURTS}

\begin{abstract}
The New Code of Civil Procedure establishes fundamental rules of the process, among them the duty of the judge to ensure the effective contradictory, ensuring equal treatment between the parties. With that, it is up to the judge to extend procedural deadlines. However, in cases such as special and extraordinary appeals, which have a double of admissibility, this delay may give rise to problems as regards the admission of the appeal, since the jurisdiction of the High Court is a matter for judgment and the delay in time is granted by the Court of origin. In this context, it is necessary to know not only the appeals and admissibility rules, but also the principles involved, so that in the end a just decision can be made.

Keywords: appeal. deadline. effective contradictory. judgment of admissibility. Legal certainty.

\footnotetext{
${ }^{1}$ Advogado. Especialista em Direito Público pela EPD - Escola Paulista de Direito. Mestre em Direito pela UNIMAR. E-mail: vinisp.adv@gmail.com

${ }^{2}$ Doutor e Mestre em Direito Processual Civil pela USP. Especialista em Administração de Empresas CEAG-Fundação Getúlio Vargas- SP. Especialista em Direito Tributário pelo Instituto Brasileiro de Estudos Tributários - IBET. Bacharel em Direito pela USP. Professor Doutor nos Cursos de Mestrado e Doutorado na Universidade de Marilia - Unimar. Coordenador e Professor da Pós-Graduação Lato Sensu em Direito Processual da Escola do Direito do Brasil (EDB). Advogado. Membro fundador e exPresidente do Ceapro - Centro de Estudos Avançados de Processo. Membro do Instituto Brasileiro de Direito Processual (IBDP). Membro do Instituto Brasileiro de Direito Tributário (IBDT). E-mail: rogerio@caisadvogados.com.br
} 


\section{INTRODUÇÃO}

A Lei $n^{\circ} 13.105$ de 16 de março de 2015, que instituiu o Código de Processo Civil, chamado de Novo Código, trouxe importantes inovações em seu texto, coadunando-se com as necessidades impostas pela evolução das lides.

Destaca-se como uma das novidades, a previsão expressa de normas fundamentais do processo civil, que trazem intima ligação com os direitos e garantias fundamentais, expressos no texto constitucional.

Um dos princípios tratados no rol de normas processuais fundamentais é o da igualdade ou paridade de tratamento, pelo qual deve-se garantir às partes que tenham as mesmas oportunidades de se manifestar no processo, inclusive com as mesmas condições de influir na decisão do juiz.

Como decorrência do princípio da igualdade, o Código também trata do princípio do contraditório, determinando ao juiz o dever de zelar pela sua efetiva aplicação.

Em razão deste dever, um dos poderes do magistrado é o de dilatar prazos processuais. Todavia, esta situação pode gerar incertezas quando a dilação é analisada no tocante aos recursos especial e extraordinário, que detém duplo juízo de admissibilidade, um pelo tribunal de origem e outro pelo tribunal superior, que é o competente para o julgamento final do recurso.

Em razão da competência final do tribunal superior para decidir sobre o recurso excepcional, ele pode discordar da dilação de prazo concedida no tribunal de origem, inadmitindo-o.

Dessa forma, pretende-se demonstrar com a pesquisa realizada, qual a melhor solução a ser adotada, levando-se em conta outros princípios existentes no ordenamento jurídico, com raiz constitucional, evitando-se prejuízos ao jurisdicionado.

Ressalta-se que este estudo tem abordagem teórica, através de pesquisa qualitativa e descritiva, com o método hipotético dedutivo, na medida em que houve uma análise dos institutos das normas fundamentais do processo civil, dos princípios da igualdade e do contraditório, além da segurança jurídica e da proteção, dos pressupostos recursais e juízo de admissibilidade dos recursos especial e extraordinário, para após, 
apresentar a melhor solução para os casos de dilação de prazos para interposição dos recursos excepcionais.

\section{NORMAS FUNDAMENTAIS DO PROCESSO CIVIL}

A Lei ${ }^{\circ}$ 13.105, de 16 de março de 2015 que instituiu o Código de Processo Civil brasileiro, revogando o antigo Código, trouxe uma importante inovação ao estabelecer uma parte geral, cujo capítulo I trata das normas fundamentais do processo civil, contando com doze artigos.

Estes doze artigos são considerados fundamentais, na medida em que orientam todas as demais normas jurídicas processuais civis previstas e vigentes no ordenamento jurídico brasileiro (DIDIER JR., 2015, p. 61).

Percebe-se que houve uma preocupação do legislador com a Constituição Federal, uma vez que a tutela jurisdicional prestada pelo Estado Democrático de Direito, deve perseguir sempre um processo justo e com garantia de acesso à justiça (THEODORO JÚNIOR, 2015, p. 96).

Como dito acima, o capítulo que trata das normas fundamentais do processo civil brasileiro é composto de doze artigos, que versam de normas que decorrem diretamente da Constituição Federal e, também de normas infraconstitucionais.

Apesar da inserção de um capítulo no Código de Processo Civil que trate de normas fundamentais, as normas ali elencadas não são novidade, conforme prescreve Humberto Theodoro Junior: “As normas que o novo Código de Processo Civil adota como fundamentais não são, na maioria, novidades no direito brasileiro, já que decorrem diretamente das garantias explicitadas na própria Constituição, ou que nelas se compreendem, implicitamente" (THEODORO JÚNIOR, 2015, p. 96).

O capítulo do código em questão traz a previsão de doze artigos, mas este rol não é exaustivo, posto que não abrange todas as normas processuais fundamentais, a exemplo do princípio do juiz natural (CÂMARA, 2017, p. 22).

Sabendo que as normas fundamentais não se esgotam no rol do Capítulo I, conforme acima, destaca-se o princípio da segurança jurídica, que será oportuna e convenientemente tratado em momento posterior. 
Feitas estas considerações, ressalta-se que, em razão do objeto da pesquisa, interessa ao presente trabalho o estudo do artigo $7^{\circ}$ do Código de Processo Civil, que trata dos princípios do contraditório e da igualdade processual, bem como as normas deles decorrentes.

\section{PRINCÍPIOS DO CONTADITÓRIO E DA IGUALDADE PROCESSUAL - ARTIGO $7^{\circ}$}

O artigo $7^{\circ}$ do Código de Processo Civil, traz em seu texto dois importantes princípios, o da igualdade processual e o do contraditório.

Com relação ao princípio da igualdade processual (também chamado de paridade de tratamento ou paridade de armas), tem-se que seu fundamento extrai-se do artigo $5^{\circ}$, caput e inciso I, da Constituição da República.

A igualdade deve ser interpretada como a maneira pela qual o juiz (representante do Estado), deve proceder em relação às partes. Neste sentido DINAMARCO:

A igualdade perante a lei é premissa para a afirmação da igualdade perante o juiz: da norma inscrita no artigo $5^{\circ}$, caput, da Constituição, brota o princípio da igualdade processual. As partes e os procuradores devem merecer tratamento igualitário, para que tenham as mesmas oportunidades de fazer valer em juízo as suas razões. (DINAMARCO et al., 2006, p. 59).

A isonomia divide-se em formal e material, sendo que a formal é aquela consagrada na lei, sem distinção de qualquer natureza. Por outro lado, a material diz respeito à concretização da própria isonomia formal, aplicada na prática. (BULOS, 2014, p. 560).

Dessa forma, tem-se por evidente que a intenção do Constituinte, bem como do legislador foi a de conferir aos cidadãos um tratamento materialmente igual, assim como às partes de um processo judicial, na medida em que tratá-los exatamente da mesma maneira implica, em muitas situações, conferir privilégios a uns, em detrimento de outros.

Melhor esclarecendo sobre o princípio da isonomia, em sua vertente material, Rui Barbosa é preciso ao preconizar que: 
[...] a regra da igualdade não consiste senão em quinhoar desigualmente aos desiguais na medida em que se desigualam. Nesta desigualdade social, proporcionada à desigualdade natural, é que se acha a verdadeira lei da igualdade. O mais são desvarios da inveja, do orgulho ou da loucura. Tratar com desigualdade a iguais, ou a desiguais com igualdade, seria desigualdade flagrante, e não igualdade real . Os apetites humanos conceberam inverter a norma universal da criação, pretendendo, não dar a cada um, na razão do que vale, mas atribuir o mesmo a todos, como se todos se equivalessem. (BARBOSA apud BULOS, 2014, p. 553-554).

Percebe-se que a função do princípio é colocar as partes em pé de igualdade no processo, com paridade de armas, para que não haja desequilíbrio na relação jurídicoprocessual, conferindo a elas as mesmas oportunidades de atuação, com os mesmos instrumentos, na tentativa de convencer o juízo.

O princípio da paridade de armas tem íntima ligação com o princípio do contraditório, tanto que ambos foram tratados no mesmo artigo $7^{\circ}$ do Código de Processo Civil. Ressaltando-se que o contraditório é também previsto nos artigos $9^{\circ} \mathrm{e}$ 10.

A definição do contraditório é extraída das lições de Artur César de Souza, que assim entende:

Concebe-se o contraditório, portanto, como sendo garantia fundamental do homem, que lhe assegura a participação dialética na concretização de um determinado provimento decorrente do exercício do Poder, como forma de assegurar a legitimidade da ingerência da decisão no trinômio vida-liberdade-propriedade, mediante uma atuação efetiva, concreta e bilateral em todo arco de um procedimento configurado segundo os ditames políticos do Estado Democrático de Direito (SOUZA, 2003, p. 170)

Assim como o princípio da igualdade processual, o contraditório também tem fundamento na Constituição da República, conforme o disposto no artigo $5^{\circ}$, inciso LV, que assegura aos litigantes em processo judicial ou administrativo a garantia do contraditório e da ampla defesa.

Este princípio é formado por um binômio CIÊNCIA/MANIFESTAÇÃO, ou seja, para que haja obediência ao contraditório é necessário que a parte seja cientificada do ato processual, bem como permita-se a sua manifestação/reação (BUENO, 2014, p. 131). 
O binômio acima descrito representa as dimensões do princípio, sendo uma formal, que implica no direito de participação no processo, ouvindo-se as partes, e; uma substancial, pela qual não basta a simples participação, na medida em que esta deve ser efetiva, capaz de influenciar a decisão do magistrado (DONIZETTI, 2014, p. 94).

Assim, percebe-se que diante do novo modelo processual que se põe, a garantia do contraditório exige que as partes tenham condições de influenciarem a decisão, não bastando a simples ciência e manifestação. Neste sentido Daniel Amorim Assumpção Neves:

Percebeu-se, muito por influência de estudos alemães sobre o tema, que o conceito tradicional de contraditório fundado no binômio "informação + possibilidade de reação" garantia tão somente no aspecto formal a observação desse princípio. Para que seja substancialmente respeitado, não basta informar e permitir a reação, mas exigir que essa reação no caso concreto tenha real poder de influenciar o juiz na formação de seu convencimento. A reação deve ser apta a efetivamente influenciar o juiz na prolação de sua decisão, porque em caso contrário o contraditório seria mais um princípio "para inglês ver", sem grande significação prática. O "poder de influência" passa a ser, portanto, o terceiro elemento do contraditório, tão essencial quanto os elementos da informação e da reação. (NEVES, 2016, p. 227) g.n.

É através da dimensão substancial do princípio do contraditório que se impede as decisões surpresas, conforme previsto nos artigos $9^{\circ}$ e 10 do Código de Processo Civil, salvo, por óbvio, as exceções expressamente elencadas.

O Poder Judiciário não deve valer-se de julgamentos repentinos, ainda mais quando as partes não foram ouvidas, quando não apresentaram seus fundamentos relativos aos fatos ou direito, ainda que se trate de matéria que o juiz possa conhecer de ofício.

Esse impedimento encontra seu fundamento no princípio do contraditório, que por sua vez tem sua gênese no princípio democrático, na medida em que o Estado Democrático não compactua com atos inesperados, especialmente do Poder Judiciário (DIDIER JÚNIOR, 2015, p. 79).

O princípio do contraditório deve ser assegurado às partes, mas é de estrita observância por todos os sujeitos processuais, incluindo-se aí o juiz, que por expressa previsão legal, tem o dever de zelar pelo efetivo contraditório, conforme consta da parte final do artigo $7^{\circ}$ do Código de Processo Civil. 
A previsão normativa acima referida, apesar de nova na legislação processual civil, nada mais é do que a concretização dos princípios constitucionais da igualdade e do contraditório (DIDIER JÚNIOR, 2015, p. 84).

O juiz, conforme previsto no artigo 139 do Código de Processo Civil, dirigirá o processo de acordo com as normas previstas no código. Dentre as incumbências do juiz na direção do processo, destaca-se a do inciso I e VI, que se relacionam com os princípios estudados.

No inciso I, do artigo 139 o juiz tem o dever de assegurar igualdade de tratamento às partes e, no inciso VI, existe o poder de dilatar prazos, dentre outros. Estas coadunam-se com o seu dever de zelar pelo efetivo contraditório no processo.

A questão de dilação de prazos processuais pelo juiz, na consecução de seu dever de zelar pelo efetivo contraditório, em uma rápida análise, parece ser simples. Todavia, quando se examinam os pressupostos recursais extrínsecos, especificamente a questão da tempestividade, pode-se ter problemas quanto aos recursos especial e extraordinário, que têm duplo juízo de admissibilidade, na medida em que o tribunal superior pode discordar da dilação de prazo conferida pelo tribunal inferior.

Diante deste problema, faz-se necessário o estudo dos pressupostos recursais, de maneira geral e, especificamente a questão do juízo de admissibilidade dos recursos especial e extraordinário.

\section{JUÍZO DE ADMISSIBILIDADE E PRESSUPOSTOS RECURSAIS}

Antes de tratar especificamente dos pressupostos recursais, vale lembrar o conceito de recurso, que nas palavras de Dinamarco: "é um ato de inconformismo mediante o qual a parte pede nova decisão diferente daquela que lhe desagrada ou prejudica." (DINAMARCO; LOPES, 2016, p. 204).

O recurso é um instrumento processual posto à disposição da parte que se sente prejudicada pela decisão/sentença, buscando uma nova decisão, a ser proferida, normalmente, por outro órgão julgador, de um grau superior de jurisdição, mas dentro da mesma relação jurídica processual, evitando-se, assim, que se forme a coisa julgada.

Uma característica marcante dos recursos é a sua voluntariedade, pela qual a parte prejudicada tem o ônus de impugnar a decisão/sentença; não o fazendo, ocorrerá a 
preclusão. Em razão da voluntariedade é que o reexame necessário não é elencado no rol taxativo dos recursos, disposto no artigo 994 do Código de Processo Civil.

O recurso, assim como qualquer outro ato processual, passa por uma análise, que se desdobra em juízo de admissibilidade e juízo de mérito, necessária ao seu julgamento (CÂMARA, 2017, p. 509). É pelo juízo de admissibilidade que se verifica se estão presentes os requisitos necessários ao processamento e julgamento do recurso - juízo de mérito.

O juízo de admissibilidade é chamado de negativo, quando não estão presentes os requisitos legais e, positivo quando preenchidos os requisitos, ocasião em que se passará ao julgamento do mérito.

Pode ainda, o juízo de admissibilidade ser provisório ou definitivo, conforme ensina DIDIER:

O juízo de admissibilidade pode, ainda, ser provisório ou definitivo. Quando o recurso for interposto perante o órgão a quo (órgão que proferiu a decisão recorrida), esse poderá, a depender da previsão normativa, exercer o juízo provisório de admissibilidade. Cabe ao órgão ad quem (órgão a quem o recurso se destina) exercer o juízo definitivo de admissibilidade. (DIDIER JÚNIOR; CUNHA, 2016, p. 106)

Dessa forma, a análise do juízo de admissibilidade não preclui, na medida em que o juízo destinatário do recurso tem o poder de analisá-lo novamente, quanto aos seus requisitos. Neste sentido Artur César Souza:

Portanto, juízo positivo de admissibilidade realizado pelo juízo 'a quo' não garante que o mérito do recurso será analisado pelo juízo 'ad quem', seja pela circunstância de que pode ocorrer algum fato que torne inadmissível o recurso, seja porque a análise do juízo de admissibilidade pelo juízo 'a quo' não preclui a reavaliação desse requisito pelo juízo 'ad quem'. (SOUZA, 2017, p. 394).

Os pressupostos processuais dos recursos, que são o objeto do juízo de admissibilidade, dividem-se em intrínsecos e extrínsecos.

São pressupostos intrínsecos dos recursos, o cabimento, a legitimidade recursal, interesse recursal. São extrínsecos a tempestividade, o preparo e a regularidade formal. O pressuposto da inexistência de ato impeditivo ou extintivo do direito de recorrer não é unanimidade na doutrina, sendo que alguns, como Nelson Nery Júnior, colocam-no como requisito extrínseco. (NERY JR., 2004, p. 274) 


\subsection{Tempestividade}

Interessa ao presente artigo a análise da TEMPESTIVIDADE, pressuposto extrínseco de admissibilidade, mas antes vale destacar a crítica feita por DIDIER, quanto à sua posição como requisito extrínseco:

Talvez fosse mais adequado posicionar a "tempestividade" como requisito intrínseco do recurso. A perda do prazo significa, rigorosamente, a preclusão do direito de recorrer; ou seja: a perda do prazo relaciona-se com a existência do direito de recorrer, e não com o exercício desse mesmo direito. A questão, porém, não tem muita importância prática, e, em razão disso, por uma opção didática, este Curso apresentará os requisitos de admissibilidade dos recursos seguindo a tradicional sistematização. Fica, tão somente, essa observação, para a reflexão dos mais doutos. (DIDIER JÚNIOR; CUNHA, 2016, p. 107-108).

Entende-se por tempestividade recursal, a estrita observância do prazo legalmente estipulado para a interposição do recurso (DINAMARCO; LOPES, 2016, p. 210). O novo Código de Processo Civil, no artigo 1.003, parágrafo $5^{\circ}$, unificou os prazos para interpor e responder aos recursos, em quinze dias, salvo quanto aos embargos de declaração que têm prazo de cinco dias.

Analisado o conceito, bem como o limite temporal, parece pouco relevante o estudo da tempestividade, todavia, este é um pressuposto recursal que demanda muitas questões, conforme se verá adiante.

Um dos problemas gerados pelo Novo Código de Processo Civil, quanto à unificação dos prazos recursais em quinze dias, residiu no prazo para a interposição de agravo interno, no Supremo Tribunal Federal e no Superior Tribunal de Justiça.

A celeuma instaurou-se por conta do que dispõe o artigo 39 da Lei ${ }^{\circ} 8.038 / 90$, que estipula o prazo de cinco dias para o agravo interno, nos recursos especial e extraordinário. Entretanto o Superior Tribunal de Justiça resolveu a celeuma. ${ }^{3}$

Diante deste julgado, restou decidido que o agravo interno em matéria penal, nos recursos especial e extraordinário, continua tendo prazo de cinco dias, não se aplicando a regra do Código de Processo Civil, conforme leciona Artur César de Souza: "Portanto,

\footnotetext{
${ }^{3}$ STJ - AgRg na Rcl: 30714 PB 2016/0083866-1, Relator: Ministro REYNALDO SOARES DA FONSECA, Data de Julgamento: 27/04/2016, S3 - TERCEIRA SEÇÃO, Data de Publicação: DJe 04/05/2016
} 
no que concerne à matéria cível, houve expressa revogação dos dispositivos da Lei n. 8.038/90 e do Regimento Interno do S.T.J. e do S.T.F. quanto ao prazo para a interposição do agravo interno" (SOUZA, 2017, p. 290).

Outra questão que diz respeito à tempestividade dos recursos, são os negócios jurídicos processuais, previstos no artigo 190 do Código de Processo Civil.

Entende-se por negócio jurídico processual, a possibilidade das partes convencionarem uma certa flexibilização procedimental, observando-se os princípios constitucionais, visando dar maior efetividade ao direito material em discussão. Este instituto coaduna-se com o princípio da cooperação (THEODORO JÚNIOR, 2015, p. 486-487).

De acordo com o que restou definido no Enunciado 36 da Escola Nacional de Formação e Aperfeiçoamento de Magistrados - ENFAM, as partes podem dispor sobre prazos processuais. ${ }^{4}$

Nota-se que a possibilidade das partes flexibilizarem o procedimento, pode trazer implicações quanto à tempestividade do recurso, na medida em que elas podem dilatar o prazo legalmente previsto. Neste sentido:

Nos termos do art. 190 do Novo CPC as partes podem celebrar um acordo procedimental, sendo sem dúvida a modificação do prazo recursal um dos objetos possíveis de tal acordo. Respeitando-se a isonomia, entendo que tanto a majoração como a redução do prazo legal são passíveis de acordo entre as partes (NEVES, 2016, p. 2189).

Apenas para elucidar, quanto ao tema negócios jurídicos processuais, destaca-se a posição contrária quanto à viabilidade do instituto, nas palavras de Elias Marques de Medeiros Neto:

Nada obstante, com o devido respeito às posições contrárias, entendemos que a sistemática da flexibilização do procedimento é inviável e que, na prática, apenas servirá para gerar mais discussões de ordem processual, em detrimento da solução ou da satisfação do próprio direito material, bem como para tornar ainda mais lento o curso do processo (NETO et al., 2015, p. 505).

\footnotetext{
${ }^{4}$ http://www.enfam.jus.br/wp-content/uploads/2015/09/ENUNCIADOS-VERS\%C3\%83ODEFINITIVA-.pdf
} 
Ainda quanto à tempestividade, o Novo Código de Processo Civil trouxe uma alteração interessante, que diz respeito à comprovação de feriado local, no ato da interposição do recurso, de acordo com o artigo 1.003, parágrafo $6^{\circ}$.

Esta regra é válida, na medida em que os Tribunais não têm condições de conhecer, bem como averiguar a existência de todos os feriados locais estipulados nos municípios brasileiros (SOUZA, 2017, p. 301).

Outra novidade trazida pelo Código, quanto à tempestividade, diz respeito à previsão do artigo 218, parágrafo $4^{\circ}$, que considera tempestivo o ato processual praticado antes mesmo do termo inicial do prazo.

Esta regra é importante, na medida em que antes do Novo Código de Processo Civil, existia entendimento nos tribunais superiores de que o recurso interposto antes do início do prazo era considerado intempestivo, em típico caso da chamada "jurisprudência defensiva" (NEVES, 2016, p. 2191).

Nota-se, com todos os problemas até aqui enfrentados, que a tempestividade não é questão processual tão simples quanto parece, posto que desafia muitas situações na prática forense.

Problema interessante relativa à tempestividade, mas que ainda não existe um debate jurídico sobre ele, diz respeito à possibilidade do juiz dilatar o prazo de interposição dos recursos especial e extraordinário, na medida em que são recursos que têm duplo juízo de admissibilidade.

Sabe-se que o prazo de interposição de recurso é um prazo próprio e peremptório, assim definidos por Nelson Nery Júnior:

Prazos próprios são os fixados para o cumprimento do ato processual, cuja inobservância acarreta desvantagem para aquele que o descumpriu, consequência essa que normalmente é a preclusão.

São peremptórios os prazos que, se desatendidos, acarretam a preclusão, sendo inalteráveis e improrrogáveis por convenção das partes ou qualquer outro motivo. O juiz, excepcionalmente, pode prorrogar prazos peremptórios. (NERY JR.; NERY, 2015, p. 791792).

Dessa forma, em regra, o juiz não pode dilatar os prazos para interposição dos recursos. Todavia, diante do que dispõe o artigo 222 do Novo Código de Processo Civil, o juiz poderá dilatar os prazos onde for difícil o transporte, bem como no caso de calamidade pública, nos termos do parágrafo $2^{\circ}$ do mesmo artigo. 
Nestas situações, ainda que peremptório o prazo, como no caso dos recursos, o juiz tem o poder de dilatá-lo, ainda mais quando a situação puder colocar as partes em desigualdade, violando o artigo $7^{\circ}$ do Código de Processo Civil.

Apenas para esclarecer, quando a lei diz juiz, ela abrange também os desembargadores.

Ainda com relação à possibilidade do juiz dilatar prazos, existe controvérsia na doutrina. Daniel Amorim Assumpção Neves entende que: "Por outro lado, o juízo poderá, unilateralmente, majorar qualquer prazo processual, nos termos do art. 139, VI, do Novo CPC, em regra aplicável ao prazo recursal" (NEVES, 2016, p. 2189). Esse também é o entendimento de Fabiano Carvalho ao defender que "A lei não faz distinção sobre a natureza do prazo. Assim, peremptório (art. 222, $\S 1^{\circ}$, do CPC) ou dilatório (próprio ou impróprio), aplica-se o disposto no art. 139, inciso VI, do CPC." (CARVALHO, 2018, p. 223).

Por outro lado, há quem entenda que o juiz somente pode dilatar prazos peremptórios, nos casos previstos no artigo 222 e inciso $2^{\circ}$ do Código de Processo Civil:

\begin{abstract}
Os prazos a que se refere este inciso são apenas os de natureza dilatória, isto é, que admitem a alteração de sua duração por convenção das partes. Os prazos peremptórios, isto é, aqueles que se descumpridos, acarretam preclusão, não podem ser dilatados livremente pelo juiz (CPC $222 \S 1 .^{\circ}$ ), sob pena de se criar insegurança jurídica ou manipulação visando a outros objetivos. Apenas excepcionalmente podem ser dilatados os prazos peremptórios, como no caso de comarcas nas quais for difícil o transporte, ou de calamidade pública. (NERY JR.; NERY, 2015, p. 633).
\end{abstract}

Há ainda a corrente que entende pela impossibilidade da dilação desses prazos tidos por peremptórios. Olavo de Oliveira Neto defende que “(...) a dilação de prazos que dizem respeito à estrutura do próprio processo, como o prazo para oferecer contestação, também pode ser promovida de forma válida? Não haveria, então, ofensa ao princípio da paridade de tratamento, sendo a dilação um motivo de desiquilíbrio das partes no processo? Por todos esses motivos, cremos, o art. 218, $\S 1^{\circ}$, do CPC deve prevalecer sobre o art. 139, VI, do CPC, não podendo o juiz dilatar prazos peremptórios." (OLIVEIRA NETO, 2017, p. 628)

Assim sendo, dada a controvérsia doutrinária acerca da possibilidade do juiz dilatar o prazo para interposição de recursos, inclusive o especial e o extraordinário, se 
mostra mais conservador evitar tal pleito, para que não se tenha discussões futuras sobre a tempestividade do recurso.

Entretanto, partindo do pressuposto que tal dilação seja possível, indaga-se novamente, em caso de recursos que comportam duplo juízo de admissibilidade, o órgão competente para julgamento de mérito é obrigado a aceitar a dilação do prazo?

Para elucidar o problema, é necessário fazer-se uma análise da competência do juízo de admissibilidade dos recursos especial e extraordinário.

\section{COMPETÊNCIA PARA REALIZAR O JUÍZO DE ADMISSIBILIDADE NO RECURSO ESPECIAL E EXTRAORDINÁRIO}

O recurso especial e o extraordinário são julgados respectivamente pelo Superior Tribunal de Justiça e pelo Supremo Tribunal Federal. São considerados recursos excepcionais, posto que têm fundamento na própria Constituição e possuem fundamentação vinculada, na medida em que só podem ser interpostos nos casos previstos nos 105, inciso III e alíneas, e artigo 102, inciso III e alíneas, respectivamente.

Estes recursos são conceituados por Cassio Scarpinella como:

[...] aqueles que têm como finalidade primeira a aplicação do direito positivo na espécie em julgamento, e não, propriamente, a busca da melhor solução para o caso concreto. É esta a razão pela qual neles não há como produzir provas ou buscar o reexame daquelas já produzidas. A aplicação do direito positivo, mormente para fins de uniformização de sua interpretação, pressupõe que os fatos da causa estejam consolidados. (BUENO, 2008, p. 237).

Interessa ao presente estudo a competência para realizar o juízo de admissibilidade nos recursos excepcionais, sem retirar a importância, por óbvio dos demais requisitos destes recursos.

Como dito anteriormente, o juízo de admissibilidade pode ser definitivo ou provisório, como é o caso dos recursos aqui tratados.

Ressalta-se que a redação originária do artigo 1.030 do Código de Processo Civil, previa juízo único de admissibilidade dos recursos excepcionais, diferentemente do que ocorria no Código revogado. 
De acordo com a sistemática apresentada pelo Novo Código de Processo Civil, em sua redação originária, a competência para realizar o juízo de admissibilidade do recurso especial e do extraordinário seria somente do Superior Tribunal de Justiça e do Supremo Tribunal Federal, respectivamente, eliminando-se o juízo preliminar de admissibilidade realizado pelo tribunal de origem (SOUZA, 2017, p. 126).

Todavia, antes mesmo de entrar em vigor o Novo Código de Processo Civil, houve uma alteração legislativa, provocada pela Lei $n^{\circ} 13.256 / 2016$, que modificou o artigo 1.030, restaurando o antigo sistema previsto no Código de 1973, pelo qual os recursos excepcionais passam por um juízo preliminar de admissibilidade, realizado pelo presidente ou vice do tribunal de origem.

Conforme dito, o juízo preliminar de admissibilidade dos recursos excepcionais é realizado pelo presidente ou vice do tribunal de origem. Entretanto, antes de realizá-lo deve-se observar o disposto nos incisos I a IV do artigo 1.030, bem como o previsto no inciso V, alíneas "a" a "c". Caso não se apliquem, então far-se-á o juízo preliminar de admissibilidade, pelo qual o recurso será admitido ou não (DIDIER JÚNIOR; CUNHA, 2016, p. 317).

Dessa forma, compete ao presidente ou vice do tribunal de origem fazer somente uma análise dos pressupostos formais do recurso especial ou extraordinário, na medida em que a apreciação do mérito compete ao tribunal superior. Neste sentido, Barbosa Moreira:

Não compete ao presidente ou vice-presidente examinar o mérito do
recurso extraordinário ou especial, nem lhe é lícito indeferi-lo por
entender que o recorrente não tem razão: estaria, ao fazê-lo, usurpando
a competência do Supremo Tribunal Federal ou do Superior Tribunal
de Justiça. Toca-lhe, porém, apreciar todos os aspectos da
admissibilidade do recurso. Se o recurso é denegado, pode o
recorrente agravar de instrumento, conforme a hipótese, para o
Supremo Tribunal Federal ou para o Superior Tribunal de Justiça (art.
544). Se admitido, o pronunciamento, irrevogável (mas anulável,
quiçá mediante agravo regimental, caso haja error in procedendo).
(MOREIRA, 2009, p. 609).

Em que pese competir ao tribunal de origem realizar o juízo de admissibilidade, como já visto, o tribunal superior, que é o competente para realizar o juízo de mérito dos recursos excepcionais, também pode refazer o juízo de admissibilidade, posto que é ele 
quem detém a competência final para julgamento do recurso, conforme ensina Nery Júnior:

\begin{abstract}
A competência para o juízo de admissibilidade dos recursos é do órgão ad quem. Ao tribunal destinatário cabe, portanto, o exame definitivo sobre a admissibilidade do recurso. Ocorre que, para facilitar os trâmites procedimentais, em atendimento ao princípio da economia processual, o juízo de admissibilidade é normalmente diferido ao juízo a quo para, num primeiro momento, decidir provisoriamente sobre a admissibilidade do recurso. De qualquer sorte, essa decisão do juízo a quo poderá ser modificada pelo tribunal, a quem compete, definitivamente, proferir o juízo de admissibilidade recursal, não se lhe podendo retirar essa competência. (NERY JR., 2000, p. 225)
\end{abstract}

Portanto, em que pese existir um juízo preliminar de admissibilidade pelo tribunal de origem, é certo que o tribunal ad quem pode revê-lo, antes de apreciar o mérito do recurso excepcional.

Superada essa questão, resta agora enfrentar o problema da dilação de prazo concedida pelo desembargador, quando da prolação do acórdão, nas hipóteses legais do artigo 139, inciso VI, ou mesmo nos casos do artigo 222, ambos do Código de Processo Civil, para a interposição de recurso especial ou extraordinário, sendo este prazo dilatado aceito pelo presidente ou vice do tribunal, admitindo o recurso.

Nesta hipótese, seria justo/legal o tribunal superior inadmitir o recurso pela intempestividade?

\title{
5 DO PRINCÍPIO DA SEGURANÇA JURÍDICA
}

As relações jurídicas, inclusive a processual, devem obedecer ao primado da segurança jurídica, sob pena de instaurar-se a desordem e até mesmo um estado de exceção. Este princípio tem seu fundamento no estado democrático de direito, conforme preceitua Luiz Guilherme Marinoni:

A segurança jurídica, vista como estabilidade e continuidade da ordem jurídica e previsibilidade das consequiências jurídicas de determinada conduta, é indispensável para a conformação de um Estado que pretenda ser "Estado de Direito" (MARINONI, 2014). (sic) 
No âmbito constitucional, a segurança jurídica encontra-se arraigada em diversos outros princípios, como pode se notar no que dispõe o artigo $5^{\circ}$, caput, incisos II, XXXVI, XXXIX e XL, todos da Constituição Federal.

Nota-se, portanto, que o princípio da segurança jurídica está intimamente ligado aos direitos fundamentais.

Com relação ao processo, não há dúvidas que o princípio da segurança jurídica deve ser obedecido, em atenção ao novo sistema jurídico processual, que busca realizar um processo justo e democrático.

Confirmando a aplicação do princípio no processo civil, Marinoni aduz que:

No Código de Processo Civil, igualmente, encontram-se regras de tutela à segurança, como as que, por exemplo, tratam da preclusão, impedindo a decisão de questão já decidida ou a prática de ato processual fora do tempo. Além disso, a assistência jurídica, por exemplo, pode ser vista como uma prestação fática para a tutela da segurança jurídica, já que o advogado gratuito pode ser indispensável para o jurisdicionado poder ter os seus direitos protegidos em Juízo (MARINONI, 2014).

Como desdobramento do princípio da segurança jurídica, tem-se o princípio da confiança, pelo qual nas palavras de Canotilho:

O homem necessita de segurança para conduzir, planificar e conformar autônoma e responsavelmente a sua vida. Por isso, desde cedo se consideravam os princípios da segurança jurídica e da proteção à confiança como elementos constitutivos do Estado de Direito. Estes dois princípios - segurança jurídica e proteção da confiança - andam estreitamente associados, a ponto de alguns autores considerarem o princípio da protecãa da confiança como um subprincípio ou como uma dimensão específica da segurança jurídica. Em geral, considera-se que a segurança jurídica está conexionada como elementos objetivos da ordem pública - garantia de estabilidade jurídica, segurança de orientação e realização do direito - enquanto a proteção da confiança se prende mais com as componentes subjetivas da segurança, designadamente a calculabilidade e previsibilidade dos indivíduos em relação aos efeitos jurídicos dos actos. (CANOTILHO, 2000, p. 256) g.n.

Em razão da aplicação destes princípios (segurança jurídica e confiança), as decisões judiciais devem obedecer às regras previamente dispostas no ordenamento jurídico, mas não só isso, também à correta interpretação destas normas, amparada por outras decisões sobre o mesmo assunto, pelos princípios e pelos ensinamentos doutrinários. 
Assim sendo feito, o princípio da confiança, bem como o da segurança jurídica serão bem aplicados, conformando-se com o sistema constitucional e processual moderno.

O Novo Código de Processo Civil, ao prever um rol de normas processuais fundamentais, que, como dito, não é taxativo, com certeza recebe os princípios da segurança jurídica e da confiança como fundamento do processo.

Dessa forma, aliando-se todos os princípios até aqui mencionados, conjugandose com as regras processuais invocadas (artigo 139, inciso VI e artigo 222, ambos do Código de Processo Civil), não parece adequado ao tribunal superior inadmitir o recurso excepcional pela intempestividade, quando dilatado o seu prazo de interposição pelo tribunal de origem.

Entretanto, ainda assim algumas questões devem ser consideradas, tais como o momento para o requerimento do pedido de dilação do prazo, sendo certo que o mais pertinente é aplicar por analogia a regra prevista no parágrafo único do artigo 139 do Código de Processo Civil, entendendo-se que o pedido de dilação deve ocorrer, por óbvio, antes do encerramento do prazo.

Em ocorrendo o pedido de dilação, parece sensato que o julgador abra vista à parte contrária para que esta se manifesta, em obediência ao contraditório.

A decisão que conferir a dilação de prazo pode desafiar alguns recursos, v.g., embargos de declaração, agravo interno, mas estes, por uma questão lógica, devem seguir os prazos legalmente definidos.

Finalmente, mas sem encerrar a discussão, há a questão dos prazos em dobros, legalmente previstos no Código de Processo Civil, como é o caso da Fazenda Pública, Defensoria Pública, Ministério Público e dos litisconsortes representados por advogados de escritórios distintos, em caso de autos físicos.

Nestas hipóteses, ainda que a critério do juízo possa-se dilatar os prazos, entende-se que isto deva ocorrer em caso excepcionalíssimo, pois o legislador já garantiu a igualdade de partes e paridade de armas, para um efetivo contraditório, dobrando os prazos.

\section{CONCLUSÃO}


O Novo Código de Processo Civil trouxe importante inovação ao prever expressamente normas fundamentais do processo civil, elencadas nos artigos $1^{\circ}$ a 12 .

Importante também as lições doutrinárias no sentido de que este rol não é taxativo.

Destaca-se ainda, a necessidade do juiz observar e zelar pela efetiva aplicação e obediência do princípio do contraditório no processo judicial, isto como forma de se garantir a paridade de tratamento entre as partes litigantes.

Ressalta-se como um dos deveres do juiz, na efetiva aplicação do contraditório, a possibilidade de dilatar prazos processuais (artigo 139, inciso VI), especialmente nas hipóteses elencadas no artigo 222 do Código de Processo Civil. Dúvida maior surge quanto a possibilidade de dilatar prazos recursais, sendo que a doutrina diverge quanto a tal faculdade. No estudo optou-se por entender quanto a possibilidade, até para analisar as implicações de tal dilação.

Diante desta perspectiva, surge a dúvida quanto à possibilidade do juiz dilatar prazos para a interposição dos recursos especial e extraordinário, na medida em que são recursos que têm duplo juízo de admissibilidade, sendo a competência final para decidir sobre eles do tribunal superior.

Os pressupostos recursais são divididos em intrínsecos e extrínsecos, sendo que nos interessa no presente momento a análise da tempestividade.

No caso de dilação do prazo para a interposição do recurso excepcional, o juízo de admissibilidade (provisório) do tribunal de origem, quanto à tempestividade, deve ser positivo.

Entretanto, considerando que nos recursos excepcionais, além do juízo provisório de admissibilidade, o tribunal superior analisa novamente os requisitos do recurso (juízo definitivo), pode haver a discordância quanto à dilação do prazo para a sua interposição.

Assim sendo, diante de sua competência para o julgamento do recurso excepcional, pode o tribunal superior inadmitir o recurso, entendo-o por intempestivo.

Todavia, em razão da existência de normas e princípios processuais que parecem permitir a dilação do prazo, bem como obedecendo-se o princípio da segurança jurídica e o da confiança, que em última análise são direitos fundamentais do homem, fundados 
no Estado Democrático de Direito, inadmitir o recurso pela intempestividade, nestes casos, parece tratar-se de uma decisão inconstitucional.

Neste sentido, a melhor solução ao caso, na medida em que se a dilação de prazo para a interposição for concedida pelo próprio Poder Judiciário, amparado pelas normas processuais, em conformidade com os princípios do contraditório (efetivo) e da igualdade, não deve o tribunal superior, ainda que detentor da competência para decidir sobre o recurso, julgá-lo intempestivo.

Por se tratar de um assunto relevante ao processo civil brasileiro, este tema deve ser amplamente debatido pela doutrina e jurisprudência ou até mesmo resolvido o impasse pelo Poder Legislativo, evitando-se, assim a insegurança jurídica.

\section{REFERÊNCIAS}

ALVIM, Eduardo Arruda. Direito Processual Civil. 3. ed. São Paulo: RT, 2010.

ARAUJO, Luiz Alberto David; JÚNIOR, Vidal Serrano Nunes. CURSO DE DIREITO CONSTITUCIONAL. 8 $8^{\mathrm{a}}$ edição. São Paulo: SARAIVA, 2004.

ASSIS, Araken de. Manual dos Recursos. 1. ed. São Paulo: Revista dos Tribunais, 2007.

BRASIL. Código de Processo Civil. Lei 13.105 de 16 de março de 2015. Publicada no Diário Oficial da União em: 17 mar. 2015.

BRASIL. Constituição Federal de 1988. Promulgada em 5 de outubro de 1988.

BRASIL. STJ. Consulta de jurisprudência. Disponível em <https://stj.jusbrasil.com.br/jurisprudencia/340098702/agravo-regimental-nareclamacao-agrg-na-rcl-30714-pb-2016-0083866-1/relatorio-e-voto-340098747>. Acesso em 30 de novembro de 2017.

BRASIL. STJ. Consulta de jurisprudência. Disponível em < https://stj.jusbrasil.com.br/jurisprudencia/448438152/recurso-especial-resp-1663221-to2017-0066316-9 >. Acesso em 01 de dezembro de 2017.

BUENO, Cassio Scarpinella. Curso sistematizado de direito processual civil: Recursos, processos e incidentes nos tribunais. Sucedâneos recursais: técnicas de controle das decisões jurisdicionais, v. 5. 2. ed., rev., atual. e ampl. São Paulo: Saraiva, 2008.

Curso sistematizado de direito processual civil: teoria geral do direito processual civil, v. 1. 8. ed. rev. e atual. São Paulo: Saraiva, 2014. 
BULOS, Uadi Lammêgo. Curso de direito constitucional. 8. ed. rev. e atual. de acordo com a Emenda Constitucional n. 76/2013. São Paulo: Saraiva, 2014.

CÂMARA, Alexandre Freitas. O novo processo civil brasileiro. 3. ed. São Paulo: Atlas, 2017.

CANOTILHO, J.J. Gomes. Direito Constitucional e Teoria da Constituição. Coimbra: Almedina, 2000.

CARVALHO, Fabiano. Código de Processo civil anotado, coord. José Rogerio Cruz e Tucci ...[et al.].- 3. ed. - Rio de Janeiro: LMJ Mundo Jurídico, 2018.

CINTRA, Antonio Carlos de Araújo; GRINOVER, Ada Pelegrini; DINAMARCO, Cândido Rangel. TEORIA GERAL DO PROCESSO. 22. ed. São Paulo: Ed. Malheiros, 2006.

CUNHA, Sérgio Sérvulo da. Recurso extraordinário e recurso especial. São Paulo: Saraiva, 2010.

DIDIER JR, Fredie. Curso de direito processual civil introdução ao direito processual civil, parte geral e processo de conhecimento. 17. ed. Salvador: Ed. JusPodivm, 2015.

DIDIER JR, Fredie; CUNHA, Leonardo Carneiro da. Curso de direito processual civil nos tribunais, recursos, ações de competência originária do tribunal e querela nullitatis, incidentes de competência originária de tribunal. 13. ed. reform. Salvador: Ed. JusPodivm, 2016.

DINAMARCO, Cândido Rangel; LOPES, Bruno Vasconcelos Carrilho. Teoria geral do novo processo civil. São Paulo: Malheiros, 2016.

DONIZETTI, Elpídio. Novo código de processo civil comentado (Lei no 13.105, de 16 de março de 2015): análise comparativa entre o novo CPC e o CPC/73. São Paulo: Atlas, 2015.

Curso didático de direito processual civil. 18. ed. rev., ampl. atual. especialmente de acordo com as Leis $\mathrm{n}^{\mathrm{o}} 12.424 / 2011,12.431 / 2011$ e Lei $\mathrm{n}^{\text {o }}$ 12.810/2013. São Paulo: Atlas, 2014.

ENFAM. Seminário - O PODER JUDICIÁRIO E O NOVO CÓDIGO DE PROCESSO CIVIL. 2015 < http://www.enfam.jus.br/wp-content/uploads/2015/09/ENUNCIADOSVERS\%C3\%83O-DEFINITIVA-.pdf>. Acesso em 01 de novembro de 2017.

ENUNCIADOS DO FORUM PERMANENTE DE PROCESSUALISTAS CIVIS, 2016. São Paulo, disponível em <http://www.cpcnovo.com.br/wpcontent/uploads/2016/06/FPPC-Carta-de-Sa\%CC\%83o-Paulo.pdf>. Acesso em 29 de novembro de 2017. 
MAFFINI, Rafael. O princípio da Proteção Substancial da Confiança no Direito Administrativo. Porto Alegre: Editora Verbo Jurídico, 2006.

MARINONI, Luiz Guilherme. Os Precedentes na Dimensão da Segurança Jurídica. Revista Páginas de Direito, Porto Alegre, ano 14, n 1117, 20 de março de 2014 < http://www.tex.pro.br/artigos/261-artigos-mar-2014/6443-os-precedentes-na-dimensaoda-seguranca-juridica>. Acesso em 05 de dezembro de 2017.

MOREIRA, José Carlos Barbosa. Comentários ao Código de processo civil : Volume V, (arts. 476 a 565): (Lei $n^{o}$ 5.869, de 11 de janeiro de 1973). 15. ed. Rio de Janeiro: Forense, 2009.

NERY JUNIOR, Nelson. Teoria geral dos recursos. 6. ed. rev., ampl e reformulada. São Paulo: Editora Revista dos Tribunais, 2004.

Princípios fundamentais: teoria geral dos recursos. 5. ed., rev. e ampl., atual. com a Lei dos Recursos para os Tribunais Superiores, N. 9.756/98 e a Lei da Prática de Atos Processuais por Fax, N. 9.800/99. São Paulo: Editora Revista dos Tribunais, 2000.

NERY JUNIOR, Nelson; NERY, Rosa Maria de Andrade. Comentários ao código de processo civil. São Paulo: Editora Revista dos Tribunais, 2015.

NEVES, Daniel Amorim Assumpção. Manual de direito processual civil - Volume único. 8. ed. Salvador: Ed. Jus Podivm, 2016.

NOBLES, Antonio Valdeci; SILVA, Marcelo Amaral da. Recursos extraordinário e especial: hipóteses de cabimento e requisitos de admissibilidade. Cuiabá: Cathedral Publicações, 2006.

OLIVEIRA NETO, Olavo de; MEDEIROS NETO, Elias Marques de; OLIVEIRA, Patrícia Elias Cozzolino de. Curso de direito processual civil - Volume 1 - Parte Geral. 1. ed. São Paulo: Verbatim, 2015.

Comentários ao Código de processo Civil, coord. Cássio Scarpinella Bueno, vol. 1, São Paulo: Saraiva, 2017.

SOUZA, Artur César de. Contraditório e revelia: perspectiva crítica dos efeitos da revelia em face da natureza dialética do processo. São Paulo: Editora Revista dos Tribunais, 2003.

. Recursos no Novo C.P.C.: Teoria Geral de acordo com a Lei 13.259/2016. São Paulo: Almedina, 2017. 
Recurso extraordinário e recurso especial: (pressupostos e requisitos de admissibilidade no novo C.P.C.): de acordo com a Lei 13.256 de 4/2/2016. São Paulo: Almedina, 2017.

THEODORO JÚNIOR, Humberto. Teoria geral do direito processual civil, processo de conhecimento e procedimento comum - vol. I. 56. ed. rev., atual. e ampl. Rio de Janeiro: Forense, 2015.

WAMBIER, Tereza Arruda Alvim. Controle das decisões judiciais por meio de recursos de estrito direito e da ação rescisória. São Paulo: Editora Revista dos Tribunais, 2002. 